\title{
Tüketicilerinin Karar Verme Tarzlarının İncelenmesi: Türk Dünyası Örneği
}

\author{
Niyazi GÜMÜŞ¹ ve Şükran KARACA²
}

\section{$\ddot{O} z$}

İnsanların nasıl ve niçin alıșveriș yaptıklarının belirleyicileri, uzun yıllar boyunca birçok insan için önemli bir konu haline gelmiştir. Bu durum çeşitli tüketici tipolojilerinin araştırılması üzerinde önemli bir etkiye sahip olmuştur. Bu bağlamda bu araştırmanın amacı Türk dünyası ülkeleri olan Azerbaycan, Kazakistan, Kırgızistan, Türkiye ve Türkmenistan'da yaşayan tüketicilerin karar verme tarzları arasında farklılık olup olmadığını incelemektir. Araştırma kapsamında kolayda örnekleme yöntemine göre seçilen ve Türk dünyası ülkelerinde yaşayan 511 kişiye yüz yüze anket tekniği ile ulaşılmıştır. Araştırma sonucunda Türkmenistan'da yaşayan tüketicilerin araştırmaya konu olan diğer ülkelerdeki tüketicilere kıyasla moda ürünleri takip ettikleri, kaliteye daha fazla ağırlık verdikleri, marka bağlllı̆̆1 ve eğlence odaklılık faktörlerinde de benzer bir karar verme tarzına sahip oldukları ortaya çıkmıştır. Başka bir ifadeyle, Türkmenistan'da yaşayan tüketicilerin karar verme tarzı açısından araştırmaya konu olan diğer ülkelerde yaşayan tüketicilerden bariz şekilde ayrıştığ1 ve öne çıktığı sonucuna ulaşılmıştır.

Anabtar Kelimeler: Satın Alma Karar Tarzları, Türk Dünyası, Tüketici Tipolojileri, Tüketici Davranış1, Alışveriş

\section{Investigation of the Decision Making Styles of Consumers: Example of Turkish World}

\begin{abstract}
Determinants of how and why people shop have become an important issue for many people for many years. This situation has had a significant impact on the investigation of various consumer typologies. In this context, the purpose of this research is to examine whether there are any differences between the decision-making style of consumers living in Azerbaijan, Kazakhstan, Kyrgyzstan, Turkey and Turkmenistan of Turkish World Countries. In the scope of the research, 511 people living in Turkish world countries and selected according to easy sampling method were reached with face to face survey technique. It has emerged in consequence of research that consumers living in Turkmenistan compared to consumers in other countries subject to research follow fashion products, give more weight to quality, have a similar decision-making style in terms of brand focus and entertainment focus factors. In other words, it has made out that Consumers living in Turkmenistan clearly differentiate and stand out from consumers in other countries subject to research subject in terms of decision-making
\end{abstract}

Key Words: Purchasing Decision Styles, Turkish World, Consumer Typologies, Consumer Behavior, Shopping

Atıf İçin / Please Cite As:

Gümüş, N. ve Karaca, Ş. (2020). Tüketicilerinin karar verme tarzlarının incelenmesi: Türk dünyası örneği. Manas Sosyal Araștırmalar Dergisi, 9(2), 946-957.

Geliş Tarihi / Received Date: 12.04.2019

Kabul Tarihi / Accepted Date: 04.12.2019

\footnotetext{
${ }^{1}$ Dr. Öğr. Üyesi - Bolu Abant İzzet Baysal Üniversitesi, Bolu MYO, niyazigumus@ibu.edu.tr - ORCID: 0000-0001-8737-3114

${ }^{2}$ Doç. Dr. - Sivas Cumhuriyet Üniversitesi, Turizm Fakültesi, sukrankaraca@gmail.com - ORCID: 0000-0002-0268-1810
} 


\section{Giriş}

Bilgi ve iletişim teknolojilerinde yaşanan büyük gelişmeler, üretilen mal ve hizmetlerin çeşit ve miktarındaki önemli artışlar, kişsiselleşen pazarlama çalışmaları gibi koşullar altında tüketiciler satın alma kararı vermeye çalışmaktadırlar. Çok sayıda faktörün etkisi altında karar vermeye çalışan tüketicilerin şüphesiz sahip oldukları kültürler de bu kararlarında önemli etkiye sahiptir. Dolayısıyla, dünya pazarlarında ticari küresel entegrasyon artıkça karar alma tüketiciler için giderek daha karmaşık hale gelmektedir. Hem perakende satış mağazalarının hem de ürün çeşitliliğin giderek artması tüketiciler için muazzam bir seçim dizisi oluşturmaktadır. Gerçekten de, perakende ortamı tüketicilerin harcamaları için yarışan rakiplerle doygun hale gelmiştir (Lysonski vd., 1996, s. 10-11). Tüketicilere sunulan çok büyük ve çeşitli alısveriş seçeneklerine ek olarak birçoğu yeni ve teknolojik açıdan karmaşık olan ürünler tüketicilere sunulmaktadır. Bunlarla birlikte, tanıtım faaliyetlerinde yaşanan artış ve dağıtım kanallarının sayısı da karar alma sürecinin daha karmaşık olmasına katkıda bulunmaktadır (Mishra, 2010, s. 46). Günümüzde tüketiciler ürünler, markalar ve dağıtım kanalları açısından artan bir tercih seçeneğiyle karşı karşıya kalmaktadır.

Birçok araştırmacı, tüketici satın alma davranışını etkileyen faktörlerin araştırılmasına odaklanmıştır. Faktörlerden biri olan karar verme stilleri, tüketici davranış araştırmacılarının yıllar içinde önemli ölçüde dikkatini çekmiştir. Tüketici karar verme tarzlarını anlamak, alısveriş davranışlarıyla ayrılmaz bir ilişsi kurması nedeniyle daha da önem kazanmaktadır (Park, 2007, s. 121).

Modern pazarlama anlayışında, bir bireyin satın alma kararlarını rekabetçi ortamda nasıl aldığını anlamak için tüketici karar verme tarzlarının araştırılmasına artan bir ilgi vardır. Satın alma karar tarzı kavramı önemlidir, çünkü tüketicilerin davranış modellerini belirleme de ve pazar bölümlendirmesinde önemli bir faktördür. Tüketici karar verme tarzları pazarlama ve davranış bilimlerinde akademisyenler arasında popüler bir araştırma alanı haline gelmiştir. Sproles ve Kendall'a göre (1986, s. 267) tüketici karar verme tarzı, tüketicinin seçim yapma yaklaşımını karakterize eden zihinsel bir yönelimdir. Tüketicilerin satın alma kararlarını nasıl aldıkları ile ilgili süreçler, tüketici davranışı ve perakende stratejisi çalışmaları için çok önemlidir. Bu nedenle bu araştırma, tüketici karar verme tarzları ile ilgili mevcut tüketici davranışı literatürüne katkıda bulunma amacını taşımaktadır.

Bu bağlamda bu çalışmanın amacı; araştırmaya konu olan Azerbaycan, Kırgızistan, Kazakistan, Türkiye ve Türkmenistan'da yaşayan tüketicilerin mevcut ihtiyaçları ve tercihleri arasındaki farklılıkları daha iyi temsil eden yeni karar verme tarzlarını ortaya koymaktır.

\section{Tüketici Karar Verme Tarzları}

Karar verme tarzı, tüketicinin tercihine hükmeden, göreceli olarak kalıcı bir tüketici kişiliğine yol açan alışveriş ve satın almalara yönelik desenli, zihinsel ve bilişsel bir yönelim olarak görülmektedir (Sproles ve Kendall, 1986, s. 267). Tüketici karar verme tarzları farklı ürünler, hizmetler satın alırken tüketicilerin uyduğu temel satın alma kararlarını ifade etmektedir (Tanksale vd., 2014).Yapılan literatür incelemesinde tüketicilerin satın alma tarzlarını belirleyebilmek için üç yol önerildiği görülmektedir: psikografik / yaşam tarzı yaklaşımı, tüketici tipolojisi yaklaşımı ve tüketici özellikleri yaklaşımı (Lastovicka, 1982; Sproles ve Kendall, 1986; Mokhlis, 2009, s. 142). Tüketici tipolojisi yaklaşımı, tüketicileri birbirinden farklı sınırlı sayıda türe göre sınıflandırarak, tüketicilerin alışveriş motivasyonlarının ve tutumlarının belirli yönlerini belirlemeye çalışır (Bandara, 2014, s. 5). Öte yandan, tüketici özellikleri yaklaşımı, özellikle tüketici karar verme ile ilgili bilişsel ve duyuşsal yönelimlere odaklanmaktadır. Psikografik araştırmalar, bir tüketicinin faaliyet, ilgi ve görüş açıklamalarının tüketici kişiliklerini ölçmede ve tüketici davranışlarını tahmin etmede çok etkili olabileceğini öngörmektedir. Bu üç yaklaşım arasında, tüketici özellikleri yaklaşımı, karar vermede tüketicilerin zihinsel yönelimlerine odaklandığı için en güçlü ve açıklayıcı olarak kabul edilmiştir. $\mathrm{Bu}$ tür bir yaklaşım, tüketicilerin alışveriş görevlerini yerine getirmek için belirli karar verme özelliklerini takip ettiğini varsaymaktadır (Lysonski vd., 1996, s. 11; Tanksale vd., 2014).

Sproles ve Kendall (1986), tüketici karar verme özellikleri arasından duygusal ve bilişsel özellikleri kapsayan en temel sekiz zihinsel özelliği belirlemiştir: (1) mükemmeliyetçilik veya yüksek kalite odaklilık; (2) marka bağlılı̆̆1; (3) yenilik-moda odaklılık; (4) eğlence, hedonistik alısveriş odakllılı; (5) fiyat odakllılı; (6) dikkatsiz (düşünmeden) alışveriş; (7) marka, mağaza ve bilgi çokluğundan karar vermede zorlanma, kararsızlık ve (8) alıskanlık, marka bağlılığı odaklılık. 
Tablo 1. Tüketici Stilleri Envanteri

\begin{tabular}{|c|c|}
\hline Tüketici Tipleri & Açıklama \\
\hline $\begin{array}{l}\text { Mükemmeliyetçi, } \\
\text { yüksek kalite odaklı } \\
\text { tüketici }\end{array}$ & $\begin{array}{l}\text { Bu özellik, ürünlerde en iyi kaliteyi arayan bir tüketici ile karakterize edilir. } \\
\text { Mükemmeliyetçilikten daha yüksek olan bu tüketicilerin daha dikkatli, daha sistematik } \\
\text { veya karşılaştırmalı olarak alışveriş yapması beklenebilir. Genellikle, yeterince iyi } \\
\text { ürünlerden memnun değillerdir. }\end{array}$ \\
\hline Marka odaklı tüketici & $\begin{array}{l}\text { Bu faktörden yüksek puan alanların pahalı, iyi bilinen ulusal markalar satın alması } \\
\text { beklenirken, bir ürünün fiyatı ne kadar yüksek olursa, kalitenin o kadar iyi olduğuna } \\
\text { inanılır. Ayrıca en çok satan, reklamı yapılan markaları tercih ederler. Tüketicilerin bu } \\
\text { stili nasıl sergiledikleri belli bir düzeyde moda bilincini sergilemektedir. }\end{array}$ \\
\hline $\begin{array}{l}\text { Yenilik-moda odaklı } \\
\text { tüketici }\end{array}$ & $\begin{array}{l}\text { Bu faktör, yeni şeyler aramayı zevkli bulabilen yenilik arayanları karakterize eder. Yeni } \\
\text { şeyler aramaktan heyecan ve zevk almaları muhtemeldir. Ayrıca stillere ayak uydurmak } \\
\text { ve stil sahibi olmak bu tüketicilerin önemli yönleridir. }\end{array}$ \\
\hline Fiyat odaklı tüketici & $\begin{array}{l}\text { Bu faktör para bilinci için fiyatı ve değeri ölçer. Bu özellikten yüksek puan alan insanlar } \\
\text { özellikle satış fiyatlarının ve genel olarak düşük fiyatların bilincinde olacak ve daha da } \\
\text { önemlisi, paraları için en iyi değeri elde etmekle ilgileneceklerdir. Bu tüketicilerin } \\
\text { karşılaştırma yapan müşteriler olması muhtemeldir. }\end{array}$ \\
\hline $\begin{array}{l}\text { Ĕglence-hedonistik } \\
\text { alı̧̧veriş odaklı } \\
\text { tüketici }\end{array}$ & $\begin{array}{l}\text { Bu faktörden yüksek puan alan tüketiciler alışverişi rekreasyon ve eğlence olarak } \\
\text { görüyorlar. Bu tüketiciler alışveriş yapmak için hoş bir aktivite bulurlar ve sadece } \\
\text { eğlenmek için alışveriş yaparlar. Daha önce yapılan araştırmalarda, bu tarz "alısveriş } \\
\text { tutkunu" veya "zamanın tadını çıkar" özelliğinin tam tersiydi. }\end{array}$ \\
\hline Plansız tüketici & $\begin{array}{l}\text { Bu özellik, o anın mevcudiyetinden satın alma ve ne kadar harcadıkları veya en iyi satın } \\
\text { alma konusunda endişeli görünme eğiliminde olan insanları tanımlar. Yani, bu } \\
\text { tüketiciler alışverişlerini planlamıyorlar. }\end{array}$ \\
\hline $\begin{array}{l}\text { Karar vermede } \\
\text { zorlanan tüketici }\end{array}$ & $\begin{array}{l}\text { Bu özellik, seçilebilecek çok fazla marka ve mağaza bulunduğunu ve pazarda aşırı bilgi } \\
\text { yüklemesi yaşayan tüketicileri karakterize eder. Bu özelliğe ilişkin yüksek puanlar, seçim } \\
\text { yapmakta zorluk çeken ve tercih edilen birçok marka ve mağazayı algılar. }\end{array}$ \\
\hline $\begin{array}{l}\text { Alışkanlık, markalara } \\
\text { sadık tüketici }\end{array}$ & $\begin{array}{l}\text { Bu faktör üzerinde yüksek puan alan kişiler, favori marka ve mağazalara sahipler ve } \\
\text { bunları tekrarlama konusunda alışkanlıklar edinmişlerdir. Alışkanlık davranışları, } \\
\text { tüketici karar vermenin iyi bilinen bir özelliğidir. }\end{array}$ \\
\hline
\end{tabular}

Kaynak: Park, 2007, s. 14-17.

Bireysel tüketici karar verme stillerini belirlemek, tüketicilerin satın alma davranışlarıyla ayrıştırılamaz bağları nedeniyle, tüketici davranış araştırmacıları ve uygulayıcıları tarafından yıllar boyunca önemli bir ilgi görmüştür (Mitchell ve Bates, 1998, s. 199). Özellikle, karar verme stillerinin incelenmesi, pazarlamaciların ve perakendecilerin farklı tüketici gruplarının tercihlerini ve ihtiyaçlarını anlamak için daha iyi bir konumda olmaları bakımından önemlidir (Tai, 2005, s. 191).

\section{Literatür Taraması}

Yerli ve yabancı literatür incelendiğinde tüketicilerin karar verme tarzları ile ilgili çok sayıda çalışmanın yapıldığ1 görülmektedir. Birçok çalışma satın alma davranışı ve cinsiyet farklılıkları ile ilgili olarak önemli farklılıklar olduğunu ileri sürmüştür. Farklllıklar temel olarak sosyolojik ve biyolojik özelliklere dayanmaktadır (Darley ve Smith, 1995 s. 41; Solik, 2014, s. 204). Araştırmacılar, bilgi işlemede, hediye verme durumunda ya da perakende satış yerinin atmosferine yönelik tutumlarında erkekler ve kadınlar arasında önemli farklılıklar olduğunu ortaya koymuştur (Meyers-Levy, 1989; Meyers-Levy ve Maheswaran, 1991; Goul ve Weil, 1991; Grewal vd., 2003).

Chang vd. (2004, s. 185), kadınların hedonistik değerleri ile satın alımdan memnuniyet arasında doğrudan bir ilişki olduğunu tespit etmiştir. Carpenter ve Moore (2009, s. 73) ise, erkeklerin aksine kadınların hedonistik değeri belirgin şekilde daha yüksek algıladıklarını ve bir ürünün aracillğındaki etkileşimi, hoş ortamı ve alş̧veriş deneyimini memnuniyetle karşıladıklarını ifade etmişlerdir. Granot vd. (2010, s. 801) tarafindan yapılan çalısmada, bir mağazayı veya markayı seçerken kadınların duygusal faktörlerin etkisinde kalma ihtimalinin daha yüksek olduğunu tespit etmişlerdir. Sonuç olarak bu bağlamsal deneyimlerin marka sadakatini büyük ölçüde desteklediğini tespit etmişlerdir. Kusa vd. (2014, s. 122) tarafindan yapılan araştırmada ise; kadınlar ve erkekler arasındaki satın alma stillerinde önemli farklılıklar olduğu kanıtlanmıştır. Elde edilen bulgulara göre; hızlı tüketim ürünlerinin sürekli satın alımı, ara sıra modaya uygun ürünlerin satın alımı ve dayanıklı tüketim ürünlerinin satın alınmasında cinsiyetin önemli bir rolü olduğu tespit edilmiştir. 
Bazı araştırmacılar karar verme stillerinin ürün tipi ve alışveriş merkezi ortamından etkilenip etkilenmediğini araştırmışlardır (Bauer vd., 2006; Wesley vd., 2006). Bauer vd. (2006, s. 342) tarafından yapılan çalışmada, tüketici karar alma stillerinin ürün kategorilerine göre değiştiği sonucuna ulaşmışlardır. Wesley vd. (2006, s. 535) ise, tüketici karar alma stillerinin alışveriş merkezi ortamından bağımsız olduğunu belirtmiştir (örneğin, bölgesel ve yerel alışveriş merkezlerinde alışverişs).

Tüketicilerin karar verme tarzları sadece çevrimdışı ortamlarda değil çevrimiçi ortamda da incelenmiştir. Park (2007, s. 118) tarafindan online karar verme stilleri üzerine yapılan çalışmada, bazı karar verme stillerinin sadakat ile pozitif, bazılarının ise sadakat ile negatif ilişkili olduğunu ortaya çıkmıştır. Özellikle, üç karar verme stili (marka bilinci, mükemmeliyetçilik bilinci ve alışkanlık) sadakat ile pozitif olarak ilişkili olduğu tespit edilmiştir. Bu araştırma karar verme stillerinin sadakat bağlamında göz önünde bulundurulması gerektiğini göstermektedir.

Tüketicilerin karar verme tarzları farklı kuşaklarda farklı șekillerde kendini göstermektedir. Mafini ve Dhurup (2014, s. 685) tarafindan Y Kuşağı tüketicilerinin satın alma karar tarzlarını inceledikleri araştırmalarında; Y kuşağ1 tüketicilerinin, kalite bilincine sahip, marka bilincine sahip, yenilik arayan, hedonistik, seçenekler karşısında kararsız, alışkan, markalara sadık ve moda odaklı olduğunu göstermektedir. Aynı zamanda Y kuşağı tüketicilerinin yaşlarının seçenekler karşısında kararsız kalma faktörü üzerinde önemli etkisi olduğu görülmüştür. Bu bulgu, genç nesil tüketicilerin, satın alma seçenekleri arasındaki kararsızlıklarının eski nesil tüketicilerden daha fazla olduğu gerçeğini vurgulamaktadir.

Araştırmaya konu olan Orta Asya ülkeleri özellikle Kazakistan, Kırgızistan, Türkmenistan bağımsızlıklarını kazandıktan sonra piyasa ekonomisine geçiş sırasında birçok yapısal reformlar ve özelleştirme programları uygulamışlardır. Uygulanan politikalara ve ülkelerin sahip olduğu doğal kaynak zenginliklerine bağlı olarak Orta Asya ülkelerinin ekonomik büyüme performansları birbirlerinden farklı bir seyir izlemektedir (Syzdykova, 2018, s. 88). Uygulanan ekonomi politikalarının vatandaşların kişisel refahına, gelir artışına ve tüketici davranışlarına etkisi kaçınılmazdır. Elbette ortaya çıkan bu etkinin her ülkenin kendi kültürü, alışkanlıkları üzerinde farklı sonuçlarının olması da kaçınılmazdır.

Konuyla ilgili ulusal ve uluslararası literatür incelendiğinde, Lysonski vd. (1996) Yunanistan, ABD, Hindistan ve Yeni Zelanda da yaşayan tüketici karar verme tarzları açısından incelenmiştir. Ceylan, (2013), tüketici tipleri envanterinin Türk kültürüne uyarlanması, Yeniçeri ve Önal (2016), tüketici karar verme tarzlarının cinsiyet bağlamında incelenmesi, Ergin, vd., (2016) genç tüketicilerin karar verme stilleri ile sms reklamlarına yönelik tutumları arasındaki farkların incelenmesi, Yüksekbilgili (2016) tüketici karar verme tarzlarının kuşaklara göre değerlendirilmesi, Yücel (2017) beyaz eşya ürünleri üzerinde demografik özelliklerin satın alma karar tarzları üzerine etkisinin incelenmesi, Durmuş ve Battal (2018) tüketicilerin hazır giyim tercihlerinde marka, reklam arac1, tutum ve satın alma karar verme tarzlarının incelenmesi, Güven vd. (2019) tüketicilerin karar verme tarzları ile kişilik özellikleri arasındaki ilişkinin incelenmesi tüketicilerin satın alma karar tarzları ile ilgili çok fazla çalışma olduğu görülmektedir. Ancak Türk dünyası olarak bilinen ülkelerde yaşayan tüketicilerin satın alma karar tarzlarının ayrı ayrı ele alındığ1 ve ülkeler arasında kıyaslamanın yapıldığı bir çalışmaya rastlanamamıştır. Araştırmanın bu yönüyle literatüre katkıda bulunulacağı düşünülmektedir.

Tüketici karar verme tarzları açısından Türkiye ile Azerbaycan'ın karşılaştırıldığı bir araştırmada Türkiye'de yedi tüketici karar verme stilinin ve Azerbaycan'da dört tüketici karar verme tarzı ortaya çıkmıştır. Türkiye'de bulunan faktörler sırasıyla mükemmeliyetçi ve yüksek kalite bilinçlilik, marka ve kalite bilinçlilik, yenilikçilik ve modaya duyarlılık, çoklu seçeneklerde kafası karışıklı̆̆ı, marka sadakati, hedonist tüketim ve fiyat odaklılıktır. Öte yandan, Azerbaycan'da bulunan faktörler ise sırasıyla mükemmeliyetçilik ve kaliteli bilinçlilik, marka ve kalite bilinçlilik, yenilikçilik ve modaya duyarlllık ile hedonistik tüketimdir. $\mathrm{Bu}$ sonuçlar, Türkiye ve Azerbaycan'daki tüketicilerin karar verme tarzlarının benzer olduğunu göstermektedir. Azerbaycan'da Türkiye'den daha az sayıda faktör ortaya çıkması ise Azerbaycan toplumunun düşünce, kültür ve eğitim düzeyindeki farkl1lıkların bir sonucu olarak yorumlanmışır (Omarov ve Özdemiz, 2017, s. 76). Azerbaycanda yaşayan tüketicilerin satın alma kararlarında etkili olan faktörler ile ilgili bir diğer araştırmada ise ürün kalitesi en önemli faktör olarak ortaya çıkmıştır. Ürün kalitesini ise sırasıyla fiyat ve uygunluk faktörleri takip etmiştir (Alizade, 2018).

Poyraz (2017) tarafından yapılan Etnosentrik Eğilimlerin Tüketici Davranışları Üzerine Etkisi: Azerbaycan ve Türkiye Karşılaştırması başlıklı araştırmada Türkiye'deki tüketicilerin Azerbaycanlı 
tüketicilere göre satın alma kararlarında cinsiyet, medeni durum, aylık ortalama hane geliri ve meslek değişkenleri açısından daha yüksek etnosentrik eğilimde olduğu tespit edilmiştir (Poyraz, 2017, s. 184).

Konuyla ilgili olarak Kazakistan'daki genç tüketiciler üzerinde yapılan bir araştırmada genç Kazak tüketicilerin mal ve hizmet satın alırken en önemli faktör olarak kaliteyi gördükleri tespit edilmiştir. Genç tüketicilerin mal ve hizmet satın alma kararlarında kaliteden sonra ise ürünün fiyatı gelmektedir (Potluri vd., 2010). Kazakistan'da ki kadın tüketiciler üzerine yapılan bir araştırmada ise kadın tüketicilerin satın alım kararlarında sırasıyla kalite, fiyat, tasarım, indirimler, yenilik ve marka isminin etkili olduğu tespit edilmiştir. Araştırma sonucunda kalite boyutunun tüm yaş grupları arasında temel faktör olarak ortaya çıkttğ1 görümüştür (Potluri vd., 2014, s. 9).

Türkmenistan'daki tüketiciler üzerine yapılan araştırmada indirim ve promosyonlar ile fiyatların tüketicilerin satın alım kararlarında çok önemli etkisi olduğu tespit edilmiştir. Bununla birlikte ülkedeki ekonomik gelişmelerin tüketici tercihlerinde züğreç içinde değişikliklere neden olduğu da ayrıca belirtilmiştir (Işık, 2013, s. 171). Türkmenistan'da tüketiciler üzerine yapılan bir diğer araştırmada ise, marka imajının tüketici Türkmenistanlı tüketicilerin tercihleri üzerinde olumlu ve önemli bir etkisi olduğu sonucuna ulaşılmıştır (Işsk ve Yaşar, 2015, s. 148). Azerbaycan ve Kırgızistan'da ki tüketicilerin laptop, tablet ve akıllı telefon satın alma kararlarında etkili olan faktörlerin belirlenmesi üzerine yapılan bir araştırmada ise kalite, garanti süresi ve fiyat en önemli faktörler olarak tespit edilmiştir (Oktay vd., 2015).

\section{Araştırmanın Yöntemi}

$\mathrm{Bu}$ araştırma Türk dünyası ülkeleri olan Azerbaycan, Kazakistan, Kırgızistan, Türkiye ve Türkmenistan'da yaşayan tüketicilerin karar verme tarzları arasında farklılık olup olmadığını belirlemek amacıyla 2018 yılı Temmuz-Ekim ayları arasında yapılmıştır. Araştırma kapsamında geçerliliği ve güvenilirliği Dursun vd. (2013) tarafından test edilmiş ve Türkçeye uyarlanmış olan Sproles ve Kendall'ın (1986) çalışmalarında ortaya koyduğu karar verme tarzları ölçeği kullanılmıştır. Ölçek formundan hareketle oluşturulan anket formu öncelikle Türkçeye ardından araştırmaya konu ülkelerin dillerine çevrilmiştir. Oluşturulan anket formu ilgili ülkelerin dillerini bilen akademisyenler tarafindan kontrol edilmiş yanlış anlamaya neden olabilecek ifadeler düzeltilmiştir. Oluşturulan anket formu iki bölümden oluşmaktadır. İlk bölümde katılımcıların demografik özellikleri, ikinci bölümde ise karar verme tarzlarına yönelik ölçek ifadeleri yer almaktadır. Anket 5'li Likert tipi (1-Kesinlikle Katılmıyorum,..., 5-Kesinlikle Katıllyorum) olarak oluşturulmuştur. Araştırmanın evrenini söz konusu ülkelerde yaşayan tüketiciler oluşturmaktadır. Araştırma evreni ile ilgili olarak Türkiye'nin 82 milyon 3 bin (www.tuik.gov.tr/, 2019) Azerbaycan'ın nüfusunun 10 milyon 60 bin, Kazakistan'ın 14,7 milyon, Kırguzistan'ın ise 6 milyon 389 bin, Türkmenistan'ın nüfusu ise 5 milyon 770 bin olduğu bilinmektedir (www.ticaret.gov.tr 2019). Bu durumda her bir ülkeyi temsil edecek örneklem büyüklügünün en az 384 olması gerekmektedir (Altunış1k vd., 2005, s. 127). Ancak her ülkede söz konuyu kitleye ulaşmanın zaman ve maliyet açısından ortaya koyacağı zorluk nedeniyle araştırmada tesadüfi olmayan örnekleme yöntemlerinden kolayda örnekleme yöntemi tercih edilerek Azerbaycan'dan 100, Kazakistan'dan 102, Kirgizistan'dan 101, Türkiye'den 106 ve Türkmenistan'dan 102 katılımcıya ulaşılmıstır. Bu sayede toplamda ilgili ülkelerden 610 katılımcı anketine ulaşılmıştır. Ancak ülkelerden geri gelen söz konusu anketlerden eksik veri, yanlış doldurma vb. nedenlerle 99 anket analiz dişında tutularak 511 anket araştırma örneklemi olarak kabul edilmiştir. Araştırmada veri toplama yöntemi olarak yüz yüze anket yöntemi tercih edilmiştir. Anketler Kastamonu Üniversitesi'nde eğitim gören ilgili ülke vatandaşları tarafindan yüz yüze gerçekleştirilmiştir. Araştırma öncesi öğrencilere anketlerin yapılması ile ilgili kısa bir eğitim verilmiştir. Araştırmada katılımcıların demografik özelliklerini öğrenebilmek için frekans analizi yapılmıştır. Yine katılımcıların karar verme tarzlarının belirlenebilmesi için açıklayıcı faktör analizi yapılmıştır. Araştırmada kullanılan ölçeğin güvenirliği Cronbach Alfa katsayı yöntemi ile test edilmiştir. Araştırmada kullanılan ölçeğin orijinal halinde toplamda 8 faktör bulunmakladır. Ancak Türk dünyası ülkelerini (Azerbaycan, Kazakistan, Kırgizistan, Türkiye, Türkmenistan) kapsayan bu araştırmada toplamda 7 faktör ortaya çıkmıştır. Ortaya çıkan söz konusu farklılı̆ın kültürel, coğrafi vb farklılıklardan kaynakladığı ve kabul edilebilir düzeyde olduğu değerlendirilmektedir. Araştırmanın amacı doğrultusunda ilgili ülkelerde yaşayan tüketicilerin karar verme tarzları arasında farklılık olup olmadığını belirleyebilmek amacıyla Tek Yönlü Anova (Varyans) Analizi yapılmıştır. Araştırmada verilerin analizinden SPSS programından yararlanılmıstır. Araştırmanın amacı doğrultusunda aşağıdaki hipotez oluşturulmuştur:

$\mathrm{H}_{1:}$ Azerbaycan, Kazakistan, Kırgizistan, Türkiye ve Türkmenistan'da yaşayan tüketicilerin karar verme tarzları arasında farklilık vardır. 


\section{Bulgular}

Bu bölümde araştırmaya katılan cevaplayıcıların demografik özellikleri ile karar verme tarzlarına yönelik açıklayıcı faktör analizi ile tek yönlü ANOVA (varyans analizi) bulguları yer almaktadır.

Tablo 2. Katzlmmclarn Demografik Özellikleri

\begin{tabular}{|c|c|c|c|c|c|}
\hline Ülke & $F$ & $\%$ & Ĕgitim & $\mathbf{F}$ & $\%$ \\
\hline Azerbaycan & 100 & 19,6 & Temel eğitim & 28 & 5,5 \\
\hline Kazakistan & 102 & 20,0 & Lise & 38 & 7,4 \\
\hline Kırgizistan & 101 & 19,8 & Ön Lisans & 152 & 29,7 \\
\hline Türkiye & 106 & 20,7 & Lisans & 246 & 48,1 \\
\hline Türkmenistan & 102 & 20,0 & Lisansüstü & 47 & 9,2 \\
\hline Cinsiyet & $F$ & $\%$ & Medeni Durum & $F$ & $\%$ \\
\hline Kadın & 277 & 54,2 & Evli & 93 & 18,2 \\
\hline Erkek & 234 & 45,8 & Bekar & 418 & 81,8 \\
\hline Meslek & $F$ & $\%$ & Gelir & $F$ & $\%$ \\
\hline Öğrenci & 363 & 71,0 & 1000 TL ve Alt1 & 259 & 50,7 \\
\hline Özel sektör çalıșanı & 72 & 14,1 & 1001 TL -2000 TL & 128 & 25,0 \\
\hline Kamu sektörü çalışanı & 24 & 4,7 & 2001 TL-3000 TL & 79 & 15,5 \\
\hline Tacir/esnaf & 23 & 4,5 & 3001 TL-4000 TL & 24 & 4,7 \\
\hline Diğer & 29 & 5,7 & 4001 TL ve Üstü & 21 & 4,1 \\
\hline Yaş & $\mathbf{F}$ & $\%$ & & & \\
\hline $16-20$ & 144 & 28,2 & & & \\
\hline $21-25$ & 266 & 52,1 & & & \\
\hline $26-30$ & 38 & 7,4 & & & \\
\hline $31-35$ & 32 & 6,3 & & & \\
\hline $36-40$ & 31 & 6,1 & & & \\
\hline Toplam & 511 & 100 & Toplam & 511 & 100 \\
\hline
\end{tabular}

Tablo 2'de katılımcıların genel olarak demografik özelliklerine yönelik bilgiler yer almaktadır. Tabloya göre; katılımcıların yarıdan fazlası kadın ve büyük çoğunluğu bekârdır. Yine katılımcıların önemli bir kısmının öğrenci ve lisans mezunu olduğu, yine yaklaşık yarısının 21-25 yaş aralığında olduğu ve aylık ortalama 1000 TL ve altı kişisel gelire sahip oldukları anlaşılmaktadır.

Araştırmanın gerçekleştirildiği ülkelerdeki katılımcıların demografik özelliklerine ayrı ayrı bakıldığında ise ilk olarak Azerbaycan'dan katılan katılımcıların kadın ve erkek oranı birbirine yakındır. Katılımciların büyük çoğunluğu öğrenci, ön lisans mezunu, 16-20 yaş arasında ve bekârdır. Ayrıca katılımcıların büyük çoğunluğunun aylık ortalama kişisel geliri 1000 TL ve altındadır.

Kırgızistan'dan araştırmaya katılan bireylerin demografik özelliklerine bakıldığında ise katılımcıların büyük çoğunluğu kamu sektörü çalışanıdır. Yine büyük çoğunluk lisans mezunu, 21-25 yaş arasında ve bekâr olduğunu belirtmiştir. Katılımcıların büyük çoğunluğunun aylık ortalama kişisel geliri ise 2001 TL3000 TL arasında bulunmaktadır. Araştırmaya Kazakistan'dan katılan katılımcıların demografik özellikleri incelendiğinde ise katılımcıların büyük çoğunluğunun kamu sektörü çalışanı olduğu, 21-25 yaş arasında olduğu, aylık ortalama kişisel gelirlerinin ise 2001 TL-3000 TL arasinda olduğu, yine büyük çoğunluğun bekâr olduğu ve lisans mezunu olduğu verdikleri bilgilerden anlaşılmaktadır. Araştırmaya Türkiye'den katılan katılımcıların demografik bilgilerine bakıldığında ise çoğunluk öğrenci, bekar ve 21-25 yaş arasındadır. Son olarak katılımcıların aylık ortalama kişisel gelirleri ise 1000 TL ve altında olarak tespit edilmiştir.

Son olarak araştırmaya Türkmenistan'dan katılan katılımcıların demografik özellikleri incelendiğinde ise büyük çoğunluğun kadın ve öğrenci olduğu, büyük çoğunluğun bekâr olduğu, 21-25 yaş arasında olanların çoğunlukta olduğu ve yine çoğunluğun aylık ortalama kişisel gelirinin 1000 TL ve altında olduğu tespit edilmiştir.

\section{Faktör Analizi}

Tablo 3. KMO ve Bartlett's Testi

\begin{tabular}{lll}
\hline \multicolumn{2}{c}{ KMO and Bartlett's Test } & \\
\hline Kaiser-Meyer-OlkinMeasure of SamplingAdequacy. & &, 756 \\
\hline \multirow{3}{*}{ Bartlett's Test of Sphericity } & Approx. Chi-Square & 1914,617 \\
\cline { 2 - 3 } & Df & 210 \\
\cline { 2 - 3 } & Sig. &, 000 \\
\hline
\end{tabular}


Analiz sonucunda, elde edilen Bartlett Küresellik Testi (Bartlett's Test of Sphericity) değerleri değişkenler arasında faktör analizi yapmaya yeterli düzeyde ilişki olduğunu göstermektedir (p: .000, Ki Kare: 1914,617, Serbestlik Derecesi: 210).

Tablo 4. Açılayıı Faketör Analiži

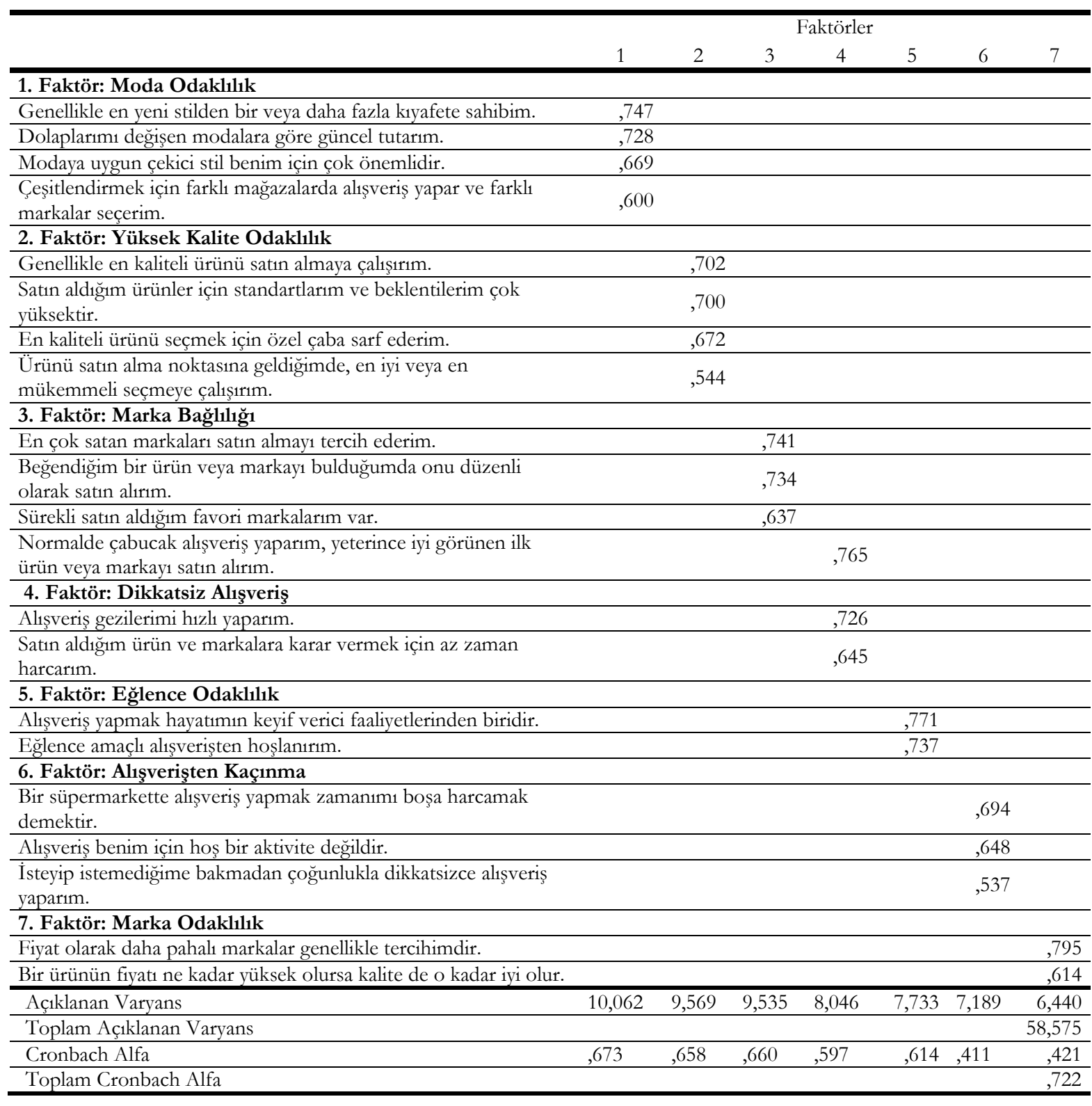

Araştırmada katılımcıların karar verme tarzlarının belirlenmesine yönelik olarak açılayıcı faktör analizi yapılmıştır. Faktör analizinde öz değeri (eigenvalue) 1'den daha büyük ve minimum yükleme büyüklügü olarak 0.30 kriteri kullanılmıştır. Bunun sebebi ise bir maddenin bir yapıy1 ya da faktörü iyi ölçtüğünü söyleyebilmek için bu faktör yükünün değerinin 0.30 ya da bu değerin üstünde bir değer olmas1 gerekliğindendir (Kline, 1994, Akt., Karaman, 2015, s. 31). Yapılan açıklayıcı faktör analizi sonucunda Tablo 4’te görüldüğü gibi 7 faktör ortaya çıkmıştır. Bu faktörler sırasıyla Moda Odaklılık, Yüksek Kalite Odaklılık, Marka Bağlllı̆̆1, Dikkatsiz Alısveriş, Eğlence Odaklılık, Alışverişten Kaçınma ve Marka Odaklılık faktörleridir. Araştırmada orijinal ölçekte bulunan "Kafa Karışıklığ1 Faktörü" ile "Fiyat Bilinci Faktörü" ortaya çıkmamıştır. Araştırmada orijinal ölçekten farklı olarak "Alısverişten Kaçınma" boyutu ortaya çıkmıştır. Bu faktör, orijinal ölçekte yer alan eğlence odaklı alışveriş yapma eğilimini ölçmeyi amaçlayan ters (reverse) sorulmuş soruları içermektedir. Bu durumda ortaya çıkan bu faktör alışverişten kaçınma olarak isimlendirilmiştir. Orijinal ölçekten farklı olarak ortaya çıkan bu durumun ülkelerin sosyal-kültürel özelliklerinin farklı olması ve/veya ülke örneklemlerinin az olmasının bir sonucu olduğu düşünülmektedir. Ayrıca Aynı durum Dursun vd. (2013) tarafindan yapılan araştırmada da ortaya çıkmıştır. Dursun vd. (2013) çalışmasında "Fiyat odaklılık", "Düşünmeden alısveriş" ve "Alışverişten kaçınma" faktörlerinde 
sorunlar tespit edilmiş ve bu sorunların farklı araştırmalarda da (Hafstrom, Chae ve Chung, 1992; Darvasula, Lysonski ve Andrews, 1993; Shim, 1996) ortaya çıktı̆̆ belirtilmiştir.

Sonuç olarak ortaya çıkan bu faktörler katılımcıların karar verme tarzlarının 58,575'lik bir kısmını açıklamaktadır. Değişkenlerin güvenilirlik değeri olan Cronbach Alfa ise, 722 çıkmış ve bu değerin ortalamanın üzerinde olduğu görülmüştür.

\section{Varyans Analizi (One-Way ANOVA)}

Katılımcıların ülkeleri ile karar verme tarzlarına yönelik ortaya çıkan faktörler arasında istatistiksel açıdan farklılık olup olmadığını anlamak amacıyla Tek Yönlü Varyans analizi yapılmıştır. Analize ilişkin bilgiler Tablo 5 'te yer almaktadır.

Tablo 5. Katıllmollarn Ülkeleri İle Karar Verme Tarælar Anova Testi

\begin{tabular}{|c|c|c|c|c|c|c|c|c|}
\hline Faktörler & & Gruplar & $\mathbf{N}$ & Ort & $\begin{array}{c}\text { Std } \\
\text { Hata }\end{array}$ & F & Sig. & Farklılık \\
\hline \multirow{5}{*}{ Moda Odaklılık } & A & Azerbaycan & 100 & 2,8500 & ,08149 & \multirow[t]{5}{*}{5,330} & \multirow[t]{5}{*}{,000 } & $E>D$ \\
\hline & B & Kazakistan & 102 & 2,6005 & ,08991 & & & $E>B$ \\
\hline & $\mathrm{C}$ & Kurgızistan & 101 & 2,9134 & 05478 & & & \\
\hline & $\mathrm{D}$ & Türkiye & 106 & 2,7571 & ,09652 & & & \\
\hline & $\mathrm{E}$ & Türkmenistan & 102 & 3,1275 & ,09102 & & & \\
\hline \multirow{5}{*}{$\begin{array}{l}\text { Yüksek Kalite } \\
\text { Odakll1lk }\end{array}$} & $\mathrm{A}$ & Azerbaycan & 100 & 3,0375 & ,09557 & \multirow[t]{5}{*}{25,118} & \multirow[t]{5}{*}{,000 } & $A>B$ \\
\hline & B & Kazakistan & 102 & 2,6618 & 07941 & & & $D>A \quad E>A$ \\
\hline & $\mathrm{C}$ & Kurgızistan & 101 & 2,9282 & 05566 & & & $\mathrm{E}>\mathrm{B} \quad \mathrm{E}>\mathrm{C}$ \\
\hline & $\mathrm{D}$ & Türkiye & 106 & 3,5142 & 07147 & & & $\mathrm{D}>\mathrm{B} \quad \mathrm{D}>\mathrm{C}$ \\
\hline & $\mathrm{E}$ & Türkmenistan & 102 & 3,5931 &, 08921 & & & \\
\hline \multirow{7}{*}{ Marka Bağlılı̆̆1 } & $\mathrm{A}$ & Azerbaycan & 100 & 2,8733 & 09473 & \multirow[t]{5}{*}{34,759} & \multirow[t]{5}{*}{,000 } & $A>B$ \\
\hline & $\mathrm{B}$ & Kazakistan & 102 & 2,1895 & ,08831 & & & $\mathrm{C}>\mathrm{B} \mathrm{D}>\mathrm{A}$ \\
\hline & $\mathrm{C}$ & Kırgızistan & 101 & 2,7525 & 07337 & & & $\mathrm{D}>\mathrm{B} \mathrm{D}>\mathrm{C}$ \\
\hline & $\mathrm{D}$ & Türkiye & 106 & 3,3239 & 06052 & & & $\mathrm{E}>\mathrm{A} E>B$ \\
\hline & $\mathrm{E}$ & Türkmenistan & 102 & 3,4183 & ,09849 & & & $\mathrm{E}>\mathrm{C} \quad \mathrm{C}>\mathrm{B}$ \\
\hline & $\mathrm{A}$ & Azerbaycan & 100 & 2,7267 & 09516 & \multirow[t]{5}{*}{9,590} & \multirow[t]{5}{*}{, 000 } & $\mathrm{C}>\mathrm{B}$ \\
\hline & B & Kazakistan & 102 & 2,4150 & 09011 & & & $\mathrm{D}>\mathrm{A}$ \\
\hline \multirow{3}{*}{ Dikkatsiz Alışveriş } & $\mathrm{C}$ & Kirgizistan & 101 & 2,9538 & 07327 & & & $\mathrm{D}>\mathrm{B}$ \\
\hline & $\mathrm{D}$ & Türkiye & 106 & 3,1415 & 08812 & & & $\mathrm{E}>\mathrm{B}$ \\
\hline & $\mathrm{E}$ & Türkmenistan & 102 & 2,8627 &, 09293 & & & \\
\hline \multirow{5}{*}{ Eğlence Odaklilık } & $\mathrm{A}$ & Azerbaycan & 100 & 3,1850 & ,10793 & \multirow[t]{5}{*}{4,686} & \multirow[t]{5}{*}{,001 } & $A>B$ \\
\hline & B & Kazakistan & 102 & 2,7353 & ,11610 & & & $\mathrm{D}>\mathrm{B}$ \\
\hline & $\mathrm{C}$ & Kırgızistan & 101 & 2,9653 & 09072 & & & $\mathrm{E}>\mathrm{B}$ \\
\hline & $\mathrm{D}$ & Türkiye & 106 & 3,2358 & ,11339 & & & \\
\hline & $\mathrm{E}$ & Türkmenistan & 102 & 3,3235 &, 11816 & & & \\
\hline \multirow{5}{*}{ Marka Odaklılık } & $\mathrm{A}$ & Azerbaycan & 100 & 2,5250 & ,08944 & \multirow[t]{5}{*}{4,291} & \multirow[t]{5}{*}{,002 } & $\mathrm{C}>\mathrm{B}$ \\
\hline & $\mathrm{B}$ & Kazakistan & 102 & 2,3039 & 08899 & & & $\mathrm{E}>\mathrm{B}$ \\
\hline & $\mathrm{C}$ & Kurgizistan & 101 & 2,7822 & 07526 & & & \\
\hline & $\mathrm{D}$ & Türkiye & 106 & 2,5519 & 08234 & & & \\
\hline & $\mathrm{E}$ & Türkmenistan & 102 & 2,7353 & ,11714 & & & \\
\hline
\end{tabular}

Grupların varyanslarının homojen olduğu tespit edildikten sonra Varyans analizine geçilmiștir. Varyans analiz sonucunda araştırmaya katılan ülkeler arasında karar verme tarzları açısından "Alışverişten Kaçınma Faktörï" dışındaki tüm faktörler için istatistiksel olarak anlamlı farkllık tespit edilmiştir. $\mathrm{Bu}$ durumda $\mathrm{H}_{1}$ hipotezi kabul edilmiştir. Ortaya çıkan farklılıkların hangi faktörler ve ülkeler arasında olduğunu tespit edebilmek için ise Tukey testi sonuçlarına bakılmışıtır. Tukey testi sonuçlarının yer aldığı Tablo 5 incelendiğinde ise ilk olarak Türkmenistan'da yaşayan tüketicilerin Kazakistan ve Türkiye'de yaşayan tüketicilere göre moda odaklılık faktör ortalamasının daha yüksek olduğu görülmektedir.

Ülkeler arasındaki farklıllğa yüksek kalite odaklılık faktörü açısından bakıldığında; Azerbaycan, Türkiye ve Türkmenistan'da yaşayan tüketicilerin Kazakistan'da yaşayan tüketicilere, Türkiye ve Türkmenistan'da yaşayan tüketicilerin Azerbaycan'da yaşayan tüketicilere, yine Türkiye ve Türkmenistan'da yaşayan tüketicilerin Kırgızistan'da yaşayan tüketicilere göre faktör ortalamalarının daha yüksek olduğu tespit edilmiştir.

Bir diğer faktör olan dikkatsiz alışveriş faktörü açısından Türk dünyası ülkeleri incelendiğinde ise; Kırgızistan, Türkiye ve Türkmenistan'da yaşayan tüketicilerin Kazakistan'da yaşayan tüketicilere göre 
dikkatsiz alısveriş faktör ortalamalarının daha yüksek olduğu tespit edilmiştir. Ayrıca Türkiye'de yaşayan tüketicilerin Azerbaycan'da yaşayan tüketicilere göre dikkatsiz alışveriş faktör ortalamalarının daha yüksek olduğu araştırmada tespit edilen bir diğer bulgu olmuştur. Eğlence odaklılık faktörü açısından bakıldığında ise; Azerbaycan, Türkiye ve Türkmenistan'da yaşayan tüketicilerin Kazakistan'da yaşayan tüketicilere göre faktör ortalamalarının daha yüksek olduğu tespit edilmiştir. Son olarak marka odaklılık faktöründe ise; Kırgızistan ve Türkmenistan'da yaşayan tüketicilerin Kazakistan'da yaşayan tüketicilere göre faktör ortalamalarının daha yüksek olduğu tespit edilmiştir.

\section{Sonuç ve Öneriler}

Türkmenistan'da yaşayan tüketicilerin araştırmaya konu olan diğer ülkelerde yaşayan tüketicilere göre karar verirken moda ürünleri takip ettikleri, kaliteye daha fazla ağırlık verdikleri, marka bağlllğ̆1 ve eğlence odaklılık faktörlerinde de benzer bir durum olduğu faktör ortalamalarından ortaya çıkmaktadır. $\mathrm{Bu}$ bağlamda araştırma sonucunda genel olarak Türkmenistan'da yaşayan tüketicilerin karar verme tarzı açısından araştırmaya konu olan diğer ülkelerde yaşayan tüketicilerden bariz şekilde ayrıştığ1 ve öne çıktığ1 sonucuna ulaşılmıştır. Araştırma kapsamında ortaya çıkan bu sonuçların Türkmenistan'ın son 10 yılda en fazla zenginleşen ülkeler sıralamasında ilk sırada yer aldığı bulgusu ile örtüştüğü düşünülmektedir (Ayval, 2017).

Dikkatsiz alışveriş bağlamında ise; Türkiye'de yaşayan tüketicilerin faktör ortalamalarının araştırmaya konu diğer ülkelerde yaşayan tüketicilerin ortalamalarına göre daha yüksek olduğu sonucuna ulaşılmıştır. Dolayısıyla, Türkiye'de yaşayan tüketicilerin satın almalarını daha dikkatsiz gerçekleştirdiği söylenebilecektir. Son olarak marka odakll1ık faktöründe ise; Kırgızistan'da yaşayan tüketicilerin diğer ülkelerde yaşayan tüketicilerin ortalamalarından daha yüksek olduğu ve dolayısıyla karar verirken markaya daha fazla odaklandıkları ifade edilebilecektir.

Araştırmada ortaya çıkan Azerbaycan'da yaşayan tüketicilerin dikkatsiz alışveriş faktöründeki düşük ortalamaları, yüksek kalite odaklılık ortalamaları ve marka bağlılığındaki ortalamaları Bardakçı’nın (2014, s. 27) yaptığı çalışma ile benzerlik göstermektedir.

Mevcut araştırmada Kazakistan'ın, satın alma karar tarzları faktörlerinin tamamında en düşük ortalamaya sahip olduğu ortaya çıkmıştır. Bu bulgu Nakip ve Vural (2001:5) tarafindan Kazakistan tüketicilerinin hayat tarzı çalışmalarındaki marka merakı ve modaya düşkünlük sonuçları ile benzerlik göstermektedir. Dolayısıyla Kazakistan'da yaşayan ve araştırmaya katılan tüketicilerin satın alma karar tarzlarını belirten faktörlerin diğer ülkelerle kıyaslandığında çok etkisinin olmadığ1 yorumu yapılabilecektir.

Çivitçi (2011, s. 97) tarafindan yapılan ve Kırgızistan ile Türkiye'de yaşayan gençlerin giysi satın alma alışkanlıklarının araştırıldığı çalışmada ise, gençlerin kültürel ve sosyal düzeyleri farklı olsa da giyinme konusunda benzer davranışlar sergilediği ve onlar için ürün kalitesinin önemli olduğu tespit edilmiştir. Mevcut araştırmada yüksek kalite odakllık, marka bağllığı ve moda odaklllık faktörleri ile elde edilen bulgular Çivitçi’nin bu sonuçları ile benzerlik göstermektedir. Dikkatsiz alışveriş ile ilgili olarak ise mevcut araştırmada Kırgizistan'da yaşayan tüketicilerin dikkatsiz alışveriş ortalamaları diğer ülkelerle karşılaştırldı̆̆ında yüksek çıkmıştır. Bu sonuç Karahan ve Maksudunov'un (2010, s. 14) yaptıkları çalş̧manın bulguları ile örtüşmemektedir. Bu durumun örneklem ve zaman bağlamında değişen tüketici davranışlarından kaynaklandığı düşünülmektedir. Yine mevcut araştırmada yüksek sayılabilecek bir ortalama ile ortaya çıkan eğlence odaklılık ve moda odaklılık konusundaki Kırgız gençlerin Türk gençlerden daha fazla moda odaklı oldukları sonucu Saygılı (2011, s. 92) tarafından yapılan çalışmanın sonuçları ile örtüşmektedir.

Sonuç olarak araştırma kapsamında Türk dünyası ülkeleri olarak öne çıkan Azerbaycan, Kazakistan, Kırgızistan, Türkiye ve 'Türkmenistan'da faaliyet göstermek isteyen girişimciler açısından son derece önemli bulgular ortaya çıkmıştır. Söz konusu ülkelerde ekonomik girişim ortaya koymak isteyen marka ve firmalar bu vb. araştırmalar nedeniyle hedef pazarlarını karşılaştırma imkânı bulmaktadırlar.

Araştırmanın birtakım kısıtları bulunmaktadır. Bu kısıtlardan ilki Türk dünyası ülkeleri olarak sadece Azerbaycan, Kazakistan, Kirgizistan, Türkiye ve Türkmenistan'ın seçilmesidir. Çok daha fazla Türk dünyası ülkesinin bulunduğu bilinmektedir. Bundan sonraki çalsşmaların daha fazla ülke katılımı ile yapılması önerilmektedir. Araştırmanın bir diğer kısıtı ise ülkelerde ulaşılabilen örneklem sayılarının ülkeleri temsil etme noktasında yetersiz olmasıdır. Ancak böyle bir araştırmanın daha önce yapılmamış olması ise araştırmanın önemini ortaya koymaktadır. 


\section{Kaynakça}

Alizade, S. (2018). The effects of gender on family purchasing behavior in Azerbaijan (Yüksek Lisans Tezi). Unec Sabah, Azerbaijan State University of Economics. Azerbaycan, Bakü

Altunışık R., Coşkun, R., Bayraktaroğlu, S. ve Yıldırım, E. (2005). Sosyal bilimlerde araștırma yöntemleri-SPSS uygulamah. Sakarya Kitabevi, Sakarya.

Ayvalı, M. (2017). Son 10 Yllda En Fazla Zenginleşen Ülkeler. http://www.bireyselyatirimci.com/son-10- yilda-enfazla-zenginlesen-ulkeler// (Erişim tarihi: 05.04.2019).

Bandara, W. W. M. C. (2014). Consumer decision-making styles and local brand biasness: Exploration in the Czech republic. Journal of Competitiveness, 6(1), 3-17.

Bardakçı, H. (2014). Azerbaycanlı tüketicilerin kültürel boyutlarının tespiti ve bu boyutlar ile tüketici davranışları arasındaki ilişkinin incelenmesi. C..Ü. Sosyal Bilimler Enstitüsü Dergisi, 23(2), 15-28.

Bauer, H. H, Sauer, N. E., ve Becker, C. (2006). Investigating the relationship between product involvement and consumer decision-making styles. Journal of Consumer Behavior, 5, 342-354.

Carpenter, J. M. ve Moore, M. (2009). utilitarian and hedonic shopping value in the us discount sector. Journal of Retailing and Consumer Services, Elsevier, 16(1), 68-74.

Ceylan, H. H. (2013). Tüketici tipleri envanterinin Türk kültürüne uyarlanması. C..Ü. Sosyal Bilimler Enstitüsü Dergisi, 22(2), 41-58.

Chang, E., Burns, L.d., ve Francis, S. K. (2004). Gender differences in the dimensional structure of apparel shopping satisfaction among Korean consumers: The role of hedonic shopping value. Clothing and Textiles Research, 22(4), 185-199.

Çivitci, Ş. (2011). Kırgızistan ve Türkiye gençlerinin giysi satın alma davranışlarının karşılaştırılması. bilig, 59.

Darley, W. K. ve Smith, R. E. (1995). Gender differences in information processing strategies: An empirical test of the selectivity model in advertising response. Journal of Advertising, 24, 41-57.

Dursun, İ., Alnıç̧1k, Ü. ve Kabadayı, E. T. (2013). Tüketici karar verme tarzları ölçeği: yapısı ve boyutları. Uluslararası Yönetim Iktisat ve Isletme Dergisi, 9 (19), 293-304

Ergin, T., Esen, S. ve Tuzla, H. (2016). Genç tüketicilerin karar verme stilleri ile SMS reklamlarına yönelik tutumları arasındaki farkların incelenmesi. Yönetim ve Ekonomi Araștrmalar Dergisi, 14(2), 18-40

Gould, S. J. ve Weil, C. E. (1991). Gift-giving roles and gender self-concepts. Sex Roles, 24, 617-637.

Granot, E., Greene, H. ve Brashear, T. (2010). Female consumers: Decision-making in brand-driven retail. Journal of Business Research, 63(8), 801-808.

Grewal, D., Baker, J., Levy, M. ve Voss, G. B. (2003). The effects of wait expectations and store atmosphere evaluations on patronage intentions in service-intensive retail stores. Journal of Retailing, 79, 259-268.

Güven, E, Palamutçuoğlu, B. ve Çavuşoğlu, S. (2019). Tüketicilerin karar verme tarzları ile kişilik özellikleri arasındaki ilişkinin incelenmesi. Süleyman Demirel Üniversitesi Sosyal Bilimler Enstitüsü Dergisi, 2(33), 51-81.

Işı1k, A. ve Yaşar, M. G. (2015). Effects of brand on consumer preferences: A study in Turkmenistan. Eurasian Journal of Business and Economics, 8(16), 139-150

Işık, A. (2013). Effects of price on consumer behaviour İn Turkmenistan. Bilim ve Teknolojide Disiplinlerarası Yönelişler $164-172$

Karahan, K. ve Maksudunov, A. (2010). Tüketici bilinç değerlendirmesi: Kırgızistan örneği. Reforma İktisadi Bilimler Dergisi, 1(45).

Karaman, H. (2015). Açımlayıcı faketör analizinde kullanılan faketör çıkartma yöntemlerinin karşılaştırlması (Yüksek Lisans Tezi). Hacettepe Üniversitesi Eğitim Bilimleri Enstitüsü, Ankara

Kusa, A., Danechova, Z., Findra, S. ve Sabo, M. (2014). Gender differences in purchase decision-making styles. European Journal of Science and Theology, 10(5), 113-123.

Lastovicka, J. L. (1982). On the validation of lifestyle traits: A review and illustration. Journal of Marketing Research, 19(1), 126-138.

Lysonski, S., Durvasula, S. ve Zotos, Y. (1996). Consumer decision-making styles: A multi-country investigation. European Journal of Marketing, 30(12), 10-21.

Mafini, C. ve Dhurup, M. (2014). Assessing consumer purchasing decision styles: An empirical investigation from South Africa. International Business \&Economics Research Journal, 13(4), 679-688.

Meyers, L. J. (1989). Gender differences in information processing: A selectivity interpretation. Lexington Books, Lexington, 219260.

Meyers. L. J. ve Maheswaran, D. (1991). Exploring differences in males' and females' processing strategies. Journal of Consumer Research, 18, 63-70.

Mishra, A. (2010). Consumer decision-making styles and young-adult consumers: An Indian exploration. İsletme Arastırmalar Dergisi, 2(3), 45-62.

Mitchell, V. ve Bates, L. (1998). UK consumer decision-making styles. Journal of Marketing Management, 14, 199-225.

Mokhlis, S. (2009). An investigation of consumer decision-making styles of young-adults in Malaysia. International Journal of Business and Management, 4(4), 140-148.

Nakip, M. ve Vural, İ. (2001). Kazakistan tüketicisinin hayat tarz1. bilig-19/Güz'2001. 
Oktay, K., Gülcan, B. ve Çakır, M. (2015). The level of brand awareness in consumer electronic products: The example of Kazakhstan and Kyrgyzstan. İsletme Arastirmalar Dergisi, 7(1), 103-124

Omarov, Z. ve Özdemir, E. (2017). Decision-making styles of consumers in Turkey and Azerbaijan: A consumer styles inventory approach. PARADOKS Ekonomi, Sosyoloji ve Politika Dergisi, 13(1), 59-79.

Park, Y. A. (2007). Investigating online decision-making styles (PhD Thesis). Texas A\&M University The Office of Graduate Studies.

Potluri, R., Abikayeva, M., Usmanova, N. ve Challagundla, S. (2014). A study on Kazakh women's consumer behavior. International Journal of Industrial Distribution \& Business, 5(4), 5-11.

Potluri, R. M., Pool, G. R. ve Tatinbekovna, S. M. (2010). Young Kazakhstan consumers: Catch them if you can. Young Consumers, 11(1), 47-56

Poyraz, Ö. O. (2017). Etnosentrik eğilimlerin tüketici davranışları üzerine etkisi: Azerbaycan ve Türkiye karşılaştırması. Tüketici ve Tüketim Araștırmaları Dergisi, 9(2), 163-187.

Sayg1l1, A. (2011). Gençlerin tüketim davranıslarm etkileyen sosyo-kültürel faktörler: Sakarya üniversitesi ve Kırgzzistan Türkiye Manas Üniversitesi örneği (Doktora Tezi). Sakarya Üniversitesi Sosyal Bilimler Enstitüsü, Sakarya.

Solik, M. (2014).Charles Taylor on The Question of Cultural Recognition, Filosoficky Casopis, 62(29), 203-216.

Sproles, G. B. ve Kendall, E. L. (1986). A methodology for profiling consumer decision-making styles. The Journal of Consumer Affairs, 20, 267-79.

Syzdykova, A. (2018). Orta Asya ülkelerinde enerji tüketimi ve ekonomik büyüme ilişkisi: Panel veri analizi. $A K U ̈$ İktisadi ve Ídari Bilimler Fakültesi Dergisi, 20(1).

Tai, S. (2005). Shopping styles of working Chinese female. Journal of Retailing and Consumer Services, 12, 191-203.

Tanksale, D., Neelam, N. ve Venkatachalam, R. (2014). Consumer decision making styles of young adult consumers in India. Procedia - Social and Behavioral Sciences, 133, 211-218.

Yapraklı, Ş. ve Keser, E. (2016). Global tüketici kültürü ve etnik kimliğin ürün gruplarına göre tüketim alışkanlıkları üzerindeki etkisi: Türkiye uygulaması. The Journal of International Social Research, 9(43).

Yeniçeri, T. ve Önal, H. (2016). Tüketici karar verme tarzlarının cinsiyet kimliğine göre incelenmesi. Pazarlama ve Pazarlama Arastturmalar Dergisi, 18, 135-168

Yücel, E. (2017). Demografik özelliklerin satın alma karar tarzları üzerine etkisi: Beyaz eşya ürünleri üzerine bir uygulama. AKÜ İktisadi ve İdari Bilimler Fakültesi Dergisi, 19(2), 53-68.

Yüksekbilgili, Z. (2016). Tüketici karar verme tarzlarının kuşaklara göre değerlendirilmesi. Elektronike Sosyal Bilimler Dergisi, 15(59), 1392-1402

Wesley, S., LeHeew, M. ve Woodside, A. G. (2006). Consumer decision-making styles and mall shopping behavior: Building theory using exploratory data analysis and the comparative method. Journal of Business Research, 59, 535548.

www.ticaret.gov.t (2019). Yurtdısı Teşkilatı - Orta Asya. www.ticaret.gov.tr/yurtdisi-teskilati/orta-asya (Erişim tarihi: 25.11.2019).

www.tuik.gov.tr (2019). Adrese Dayalı Nüfus Kayı Sistemi Sonuçları, 2018. http://www.tuik.gov.tr/PreHaberBultenleri.do?id=30709 (Erişim tarihi: 25.11.2019).

\section{EXTENDED SUMMARY}

Many researchers have focused on investigating factors affecting consumer buying behavior. Decision-making styles, one of the factors, have attracted considerable attention of consumer behavior researchers over the years. Understanding consumer decision-making styles is becoming more important as it establishes an inseparable relationship with shopping behaviors (Park, 2007, p. 121). The concept of purchasing decision style is important because it is a key factor in determining consumer behavior patterns and in market segmentation. Consumer decision-making has become a popular area of research among academics in marketing and behavioral sciences. According to Sproles and Kendall (1986, p. 267), consumer decision-making is a mental orientation that characterizes the consumer's choice of choice. Processes for how consumers take purchasing decisions are crucial to the study of consumer behavior and retail strategy. Therefore, this research aims to contribute to the current literature on consumer behavior related to consumer decision-making styles.

This study Turkish world countries are Azerbaijan, Kazakhstan, Kyrgyzstan, Turkey and Turkmenistan decision making of consumers living in in order to determine whether the differences in style were made between July and October 2018. Within the scope of the research, Sproles and Kendall (1986) were based on the decision-making styles of their studies. The questionnaire form, which was formed from the scale form, was first translated into Turkish and then into the languages of the countries concerned. The questionnaire form which was formed was corrected by the academicians who know the languages of the related countries. The questionnaire form consists of two parts. In the first part, the demographic characteristics of the participants and the second part are the scale expressions for the decision-making styles. The universe of the research is composed of consumers living in these countries. 
However, due to the impossibility of reaching the audience, simple sampling method was preferred from simple random sampling methods and thus, a total of 610 participants from the related countries were reached. However, missing data from these surveys, incorrect filling and so on. 511 questionnaires were excluded from the survey. As a method of data collection, face-to-face survey method was preferred. The surveys were conducted face-to-face by the citizens of the related country who were studying at Kastamonu University. Before the research, a short training was given to the students about the surveys. In order to learn the demographic characteristics of the participants, frequency analysis was performed. In order to determine the decision-making styles of the participants, explanatory factor analysis was performed. There are 9 factors in the original scale. However, 7 factors emerged in this study, which includes the Turkish world countries. It is considered that the mentioned difference originates from cultural, geographical etc. differences and is acceptable. For the purpose of the study, One-Way Anova (Variance) Analysis was performed in order to determine whether there was any difference between the decision-making styles of the consumers living in the relevant countries. SPSS program was used to analyze the data.

The fact that consumers living in Turkmenistan follow fashion products in decision-making according to the consumers living in other countries, they give more weight to quality and they are similar in brand orientation and entertainment focus factors. In this context, it is concluded that consumers living in Turkmenistan in general are clearly differentiated and stand out from the consumers living in other countries subject to the research. It is thought that the results of this study are in line with the finding that Turkmenistan ranked first in the ranking of the most enriched countries in the last 10 years (Ayvali, 2017).

In the context of unplanned shopping; The average consumer is subject to research the factors of living in Turkey have reached the conclusion that there is higher than average consumers living in other countries. Thus, consumers living in Turkey can perform more of unplanned buying. Finally, the higher price-oriented factor; It can be said that the consumers living in Kyrgyzstan are higher than the average of the consumers living in other countries and therefore they focus more on the high price when making the decision.

The average of low average of unplanned shopping factors, quality-oriented averages and brandoriented averages of consumers living in Azerbaijan is similar to the study conducted by Bardakç1 (2014, p. 27).

In the current study, it was found that Kazakhstan had the lowest average of all purchasing decision styles. This finding is similar to that of Nakip and Vural (2001, p. 5) in terms of brand interest and fashions in lifestyle studies of Kazakhstan's consumers. Therefore, it can be said that the factors determining the purchasing decision styles of the consumers living in Kazakhstan and participating in the research do not have much effect compared to other countries.

Çivitci (2011, p. 97) and made by Kyrgyzstan in Turkey's youth clothing In studies on the buying habits of young people, cultural and social levels exhibited similar behavior in different Although the dressing and were they found to be important for product quality. In the present research, the results obtained with quality focus, brand focus and fashion orientation factors are similar to those of Çivitçi. With regard to unplanned shopping, the average of unplanned shopping of consumers living in Kyrgyzstan in the current survey is high compared to other countries. This result does not coincide with the findings of the study of Karahan and Maksudunov (2010, p. 14). This situation is thought to be caused by changing consumer behaviors in the context and time. Again, the results of the study conducted by Saygill (2011, p. 92) show that the Kyrgyz youth who are more interested in entertainment focus and fashion focus than the Turkish youth are the focus of fashion.

As a result, Azerbaijan stands out as the Turkish world countries surveyed, Kazakhstan, Kyrgyzstan, Turkey and Turkmenistan in terms of entrepreneurs who want to operate is extremely important findings emerged. In these countries, brands and firms that want to introduce economic enterprises, etc. they have the opportunity to compare their target markets. 